\title{
Methoxy polyethylene glycol-epoetin beta for anemia with chronic kidney disease
}

This article was published in the following Dove Press journal: International Journal of Nephrology and Renovascular Disease 29 March 2012

Number of times this article has been viewed

\author{
Naro Ohashi' \\ Yukitoshi Sakao \\ Hideo Yasuda' \\ Akihiko Kato ${ }^{2}$ \\ Yoshihide Fujigaki' \\ 'Internal Medicine I, ${ }^{2}$ Blood \\ Purification Unit, Hamamatsu \\ University School of Medicine, \\ Hamamatsu, Shizuoka, Japan
}

Correspondence: Naro Ohashi Internal Medicine I, Hamamatsu University School of Medicine, I-20-I Handayama, Higashi-ku, Hamamatsu 43I-3192, Japan Tel +8I 53435226 I Fax +8I 534349447 Email ohashi-n@hama-med.ac.jp
Abstract: Chronic kidney disease (CKD) is a risk factor for end-stage renal failure and cardiovascular events. In patients with CKD, anemia is often caused by decreased erythropoietin production relative to hemoglobin levels. As correction of anemia is associated with improved cardiac and renal function and quality of life, erythropoiesis-stimulating agents (ESAs) are standard therapy for anemia in CKD patients. However, traditional ESAs such as epoetin or darbepoetin have short half-lives and require frequent administration, dose changes, and close monitoring of hemoglobin concentration to maintain target hemoglobin levels. Methoxy polyethylene glycol-epoetin beta (MPG-EPO) is the only ESA that is generated by chemical modification of glycosylated erythropoietin through the integration of one specific, long, linear chain of polyethylene glycol. This ESA induces continuous erythropoietin receptor activation and has a long half-life (approximately 130 hours). Subcutaneous or intravenous administration of MPG-EPO once every 2 weeks or monthly achieved a high hemoglobin response rate in patients with anemia associated with $\mathrm{CKD}$, regardless of whether the patient was undergoing dialysis. According to data from an observational time and motion study, MPG-EPO maintains hemoglobin levels when the same dose is administered, however infrequently. This suggests that compared with the use of traditional ESAs, administration of MPG-EPO reduces the overall time and cost associated with the management of anemia in CKD patients undergoing dialysis. MPG-EPO is generally well tolerated and most adverse events are of mild to moderate severity. The most commonly reported adverse effects are hypertension, nasopharyngitis, and diarrhea. Subcutaneous injection of MPG-EPO is significantly less painful than subcutaneous injection of darbepoetin. In conclusion, MPG-EPO is as effective and safe as traditional ESAs in managing renal anemia, irrespective of whether the patient is undergoing dialysis.

Keywords: methoxy polyethylene glycol-epoetin beta, renal anemia, end-stage renal failure, hemoglobin, erythropoiesis-stimulating agent

\section{Introduction}

Chronic kidney disease (CKD) is a known risk factor for end-stage renal failure and cardiovascular events. ${ }^{1}$ Anemia is a common complication in patients with CKD. The most probable reason for a decline in hemoglobin levels in CKD patients is decreased erythropoietin production relative to hemoglobin levels. ${ }^{2}$ Correction of anemia is associated with improved cardiac and renal function and quality of life. ${ }^{3}$ Therefore, erythropoiesis-stimulating agents (ESAs) are standard therapy for renal anemia in CKD patients.

ESAs are glycated proteins with a peptide core of 165 amino acids. A major limitation of epoetin, the first ESA to be marketed, is that it is usually administered by 
injection two or three times per week. ${ }^{4}$ To develop a longeracting erythropoietic agent, additional $N$-linked glycosylation sites were introduced into erythropoietin by site-directed mutagenesis. ${ }^{5}$ This modification resulted in a $37.1-\mathrm{kDa}$ glycoprotein, darbepoetin alfa (DA), the half-life of which is three times that of epoetin, thus only needs to be administered by injection once weekly, or once every 2 weeks in most patients. ${ }^{6,7}$ However, conventional treatment with ESAs to manage anemia in CKD patients requires frequent administration, dose changes, and close monitoring of hemoglobin concentration to maintain target hemoglobin levels.

Methoxy polyethylene glycol-epoetin beta (MPG-EPO; Mircera $^{\circledR}$, Roche, Basel, Switzerland) is a novel agent that has a different interaction with the erythropoietin receptor than previous agents and has a long elimination half-life (approximately 130 hours). ${ }^{8}$ MPG-EPO is the only ESA generated by chemical modification of glycosylated erythropoietin, by the integration of one specific, long, linear chain of polyethylene glycol. The resultant molecule has a molecular weight of approximately $60 \mathrm{kDa}$, which is twice that of epoetin. The methoxy polyethylene glycol polymer chain is integrated through amide bonds between the $N$-terminal amino group or the $\varepsilon$-amino group (predominantly lysine-52 or lysine-45) with a single butanoic acid linker. ${ }^{9}$

The interaction between MPG-EPO and the erythropoietin receptor differs from that of epoetin beta. ${ }^{10}$ The comparative erythropoietin receptor-binding properties of MPG-EPO and epoetin beta were assessed by surface plasmon resonance using soluble recombinant EPO receptors and by competition binding on cultured UT-7 cells. Calculated equilibrium dissociation constants (surface plasmon resonance assay) for MPG-EPO and epoetin beta were 140 and $2.9 \mathrm{nmol} / \mathrm{L}$, respectively. Respective IC50 values (competition binding assay) were 200 and $1.5 \mathrm{nmol} / \mathrm{L}$. Compared with epoetin beta, MPG-EPO has an approximately 50- to 100-fold lower affinity for erythropoietin receptor-binding sites. Analysis of the equilibrium binding curves indicates that the difference in affinity is mainly due to slower association. The different receptor-binding properties of MPG-EPO may enable continuous stimulation of erythropoiesis combined with a long half-life and slow systemic clearance. ${ }^{10}$ As a result, MPG-EPO stimulates erythropoiesis when administered intravenously or subcutaneously at a prolonged dosing interval (Table 1).

This review focuses on the therapeutic efficacy and tolerability of MPG-EPO in CKD patients with renal anemia who are or are not undergoing dialysis.

\section{Therapeutic efficacy}

Several Phase I, four Phase II, and seven Phase III randomized open-label, parallel-group, multicenter studies have investigated the therapeutic efficacy of MPG-EPO in CKD patients with renal anemia (Table 2). ${ }^{8,11-22}$ These studies have included patients who were or were not undergoing dialysis. In addition, the open-label, non-comparative (MIRACEL) study assessed the efficacy of MPG-EPO in a real-life situation. ${ }^{23}$

In a Phase I trial using healthy volunteers $(n=42)$, subcutaneous administration of MPG-EPO in the arm, thigh, or abdomen $(3.0 \mu \mathrm{g} / \mathrm{kg})$ increased mean reticulocyte counts relative to baseline by $258 \%, 273 \%$, and $269 \%$, respectively. These results suggest that the pharmacokinetic and pharmacodynamic properties of MPG-EPO effectively increase reticulocyte counts, irrespective of the skin site of subcutaneous administration. ${ }^{11}$ Similarly, in a Phase I trial in patients receiving peritoneal dialysis $(n=16)$, a single subcutaneous $(0.8 \mu \mathrm{g} / \mathrm{kg})$ or intravenous $(0.4 \mu \mathrm{g} / \mathrm{kg})$ dose of MPG-EPO induced a reticulocyte response that peaked at a median of 8 days after administration and returned to baseline values by day 20 . The time course for reticulocyte counts was not different between the two routes of administration. These results suggest that extended administration intervals of MPG-EPO are feasible in patients with CKD. ${ }^{8}$

In the Phase II trials, four studies determined the administration intervals and optimal starting dose in patients with $\mathrm{CKD}$, some of whom were undergoing dialysis, while others

Table I Half-lives of erythropoiesis-stimulating agents (ESAs)

\begin{tabular}{|c|c|c|c|}
\hline \multirow[t]{2}{*}{ ESA } & \multirow[t]{2}{*}{ Population } & \multicolumn{2}{|l|}{ Mean half-life (h) } \\
\hline & & Intravenous administration & Subcutaneous administration \\
\hline Epoetin alfa & Healthy volunteers ${ }^{4}$ & 6.8 & 19.4 \\
\hline Epoetin beta & Healthy volunteers ${ }^{4}$ & 8.8 & 24.2 \\
\hline \multirow[t]{2}{*}{ Darbepoetin alfa } & CKD patients not on dialysis ${ }^{6}$ & & 69.6 \\
\hline & CKD patients on dialysis ${ }^{7}$ & 25.3 & 48.8 \\
\hline Methoxy polyethylene glycol-epoetin beta & CKD patients on dialysis ${ }^{8}$ & 134 & 139 \\
\hline
\end{tabular}

Abbreviation: CKD, chronic kidney disease. 
Table 2 Therapeutic efficiency of methoxy polyethylene glycol-epoetin beta

\begin{tabular}{|c|c|c|c|}
\hline $\begin{array}{l}\text { Method, dose, and frequency } \\
\text { of administration }\end{array}$ & Population & Numbers & Results \\
\hline $\begin{array}{l}\text { A single SC dose }(0.8 \mu \mathrm{g} / \mathrm{kg}) \text { or IV dose } \\
(0.4 \mu \mathrm{g} / \mathrm{kg})^{8}\end{array}$ & Patients on PD & 16 & $\begin{array}{l}\text { MPG-EPO has a prolonged half-life after } \\
\text { IV (I34 h) and SC (I39 h) administration }\end{array}$ \\
\hline A single SC dose $(3.0 \mu g / k g)^{\prime \prime}$ & Healthy volunteers & 42 & $\begin{array}{l}\text { MPG-EPO increases reticulocyte counts, } \\
\text { irrespective of the skin site of SC } \\
\text { administration }\end{array}$ \\
\hline $\begin{array}{l}\text { SC doses }(0.15,0.30 \text {, and } 0.45 \mu \mathrm{g} / \mathrm{kg}) \\
\text { once every I, } 2 \text {, or } 3 \text { weeks }{ }^{12}\end{array}$ & ESA-naïve patients on dialysis & 61 & $\begin{array}{l}\text { SC dose }(0.60 \mu \mathrm{g} / \mathrm{kg}) \text { once every } 2 \text { weeks } \\
\text { is optimal in CKD patients on dialysis }\end{array}$ \\
\hline IV doses $(0.25,0.4, \text { or } 0.6 \mu \mathrm{g} / \mathrm{kg} / \text { week })^{13}$ & $\begin{array}{l}\text { Patients on dialysis converted } \\
\text { from EPO }\end{array}$ & 91 & $\begin{array}{l}\text { Administration can be switched from } \\
\text { EPO } 3 \text { times/week to MPG-EPO once } \\
\text { every I or } 2 \text { weeks }\end{array}$ \\
\hline $\begin{array}{l}\text { SC doses }(0.4,0.8 \text {, or } 1.2 \mu \mathrm{g} / \mathrm{kg}) \\
\text { once every I, } 3 \text {, or } 4 \text { weeks }^{14}\end{array}$ & $\begin{array}{l}\text { Patients on dialysis converted } \\
\text { from SC EPO }\end{array}$ & 137 & $\begin{array}{l}\text { SC MPG-EPO at up to once-monthly } \\
\text { intervals provides stable Hgb levels in } \\
\text { dialysis patients converting from EPO } \\
\text { I-3 times/week }\end{array}$ \\
\hline $\begin{array}{l}\text { SC doses }(0.15,0.3 \text {, or } 0.6 \mu g / k g) \\
\text { once every I, } 2 \text {, or } 4 \text { weeks }^{15}\end{array}$ & $\begin{array}{l}\text { ESA-naïve patients not } \\
\text { on dialysis }\end{array}$ & 91 & $\begin{array}{l}\mathrm{SC}(0.6 \mu \mathrm{g} / \mathrm{kg}) \text { dose once every } \\
2 \text { weeks is optimal in CKD patients } \\
\text { not on dialysis }\end{array}$ \\
\hline $\begin{array}{l}\text { IV dose }(0.4 \mu g / k g) \text { once every } \\
2 \text { weeks }{ }^{16} \text { (AMICUS study) }\end{array}$ & Patients on dialysis & 181 & $\begin{array}{l}\text { IV MPG-EPO once every } 2 \text { weeks is safe } \\
\text { and effective as } 3 \text { times weekly EPO } \\
\text { for correcting anemia }\end{array}$ \\
\hline $\begin{array}{l}\text { SC dose }(0.6 \mu g / k g) \text { once every } \\
2 \text { weeks }{ }^{17} \text { (ARCTOS study) }\end{array}$ & $\begin{array}{l}\text { ESA-naïve patients not } \\
\text { on dialysis }\end{array}$ & 324 & $\begin{array}{l}\text { SC MPG-EPO once every } 2 \text { weeks is as } \\
\text { safe as DA once every I week }\end{array}$ \\
\hline $\begin{array}{l}\text { IV doses }(60,100,180 \mu g) \text { once every } \\
2 \text { weeks and IV doses (I20, 200, } 360 \mu \mathrm{g}) \\
\text { once every } 4 \text { weeks }^{18} \text { (MAXIMA study) }\end{array}$ & $\begin{array}{l}\text { Patients on HD converted } \\
\text { from IV EPO }\end{array}$ & 673 & $\begin{array}{l}\text { IV MPG-EPO is as safe as conventional } \\
\text { EPO treatment and can maintain anemia } \\
\text { management from IV EPO }\end{array}$ \\
\hline $\begin{array}{l}\text { SC doses }(60,100,180 \mu g) \text { once every } \\
2 \text { weeks and SC doses (I20, 200, } 360 \mu \mathrm{g}) \\
\text { once every } 4 \text { weeks }{ }^{19} \text { (PROTOS study) }\end{array}$ & $\begin{array}{l}\text { Patients on HD converted } \\
\text { from SC EPO }\end{array}$ & 572 & $\begin{array}{l}\text { SC MPG-EPO once every } 2 \text { or } 4 \text { weeks } \\
\text { maintains tight and stable Hgb levels from } \\
\text { SC EPO }\end{array}$ \\
\hline $\begin{array}{l}\text { IV doses }(60,100,180 \mu \mathrm{g}) \text { once every } \\
2 \text { weeks }^{20}(\text { STRIATA study) }\end{array}$ & $\begin{array}{l}\text { Patients on HD converted } \\
\text { from IV DA }\end{array}$ & 313 & $\begin{array}{l}\text { Stable Hgb levels are maintained in } \\
\text { patients on HD converted IV MPG-EPO } \\
\text { every } 2 \text { weeks from DA }\end{array}$ \\
\hline $\begin{array}{l}\text { SC/IV doses }(60,100,180 \mu \mathrm{g}) \text { once every } \\
2 \text { weeks }{ }^{21} \text { (RUBRA study) }\end{array}$ & $\begin{array}{l}\text { Patients on dialysis converted } \\
\text { from SC/IV EPO }\end{array}$ & 336 & $\begin{array}{l}\text { MPG-EPO once every } 2 \text { weeks maintains } \\
\text { stable Hgb control in patients on dialysis } \\
\text { converted from EPO }\end{array}$ \\
\hline $\begin{array}{l}\text { IV doses (I20, 200, or } 360 \mu \mathrm{g}) \text { once every } \\
4 \text { weeks }^{22} \text { (PATRONUS) }\end{array}$ & $\begin{array}{l}\text { Patients on HD converted } \\
\text { from IV DA }\end{array}$ & 490 & $\begin{array}{l}\text { MPG-EPO maintains target Hgb more } \\
\text { successfully than DA }\end{array}$ \\
\hline
\end{tabular}

Abbreviations: SC, subcutaneous; IV, intravenous; PD, peritoneal dialysis; MPG-EPO, methoxy polyethylene glycol-epoetin beta; ESA, erythropoiesis-stimulating agent; CKD, chronic kidney disease; EPO, epoetin; Hgb, hemoglobin; DA, darbepoetin alfa; HD, hemodialysis.

were not. ${ }^{12-15}$ de Francisco et al investigated 61 ESA-naïve patients with CKD who were undergoing dialysis and were randomized to MPG-EPO treatment at doses of $0.15,0.30$, and $0.45 \mu \mathrm{g} / \mathrm{kg}$ once per week. ${ }^{12}$ Within these dose groups, patients were further randomized into once weekly, once every 2 weeks, or once every 3 weeks groups. In total, $90 \%$ of patients in the $0.30 \mu \mathrm{g} / \mathrm{kg}$ once per week group and $79 \%$ of patients in the $0.45 \mu \mathrm{g} / \mathrm{kg}$ once per week group responded to treatment (hemoglobin increase, $\geq 1.0 \mathrm{~g} / \mathrm{dL}$ ), compared with $72 \%$ in the $0.15 \mu \mathrm{g} / \mathrm{kg}$ once per week group and the response was unrelated to administration frequency. Provenzano et al studied administration intervals (once every 1,2 , or 4 weeks) and optimal starting doses $(0.15,0.30$, or $0.60 \mu \mathrm{g} / \mathrm{kg}$ once per week) of MPG-EPO subcutaneously administered in ESAnaïve patients with $\mathrm{CKD}$ who were not receiving dialysis. ${ }^{15}$ The hemoglobin response rate increased with escalating doses, with $67 \%, 72 \%$, and $90 \%$ of patients responding in the groups treated with MPG-EPO at $0.15,0.30$, and $0.60 \mu \mathrm{g} / \mathrm{kg}$ once per week, respectively, and the response was unrelated to administration frequency. Overall, these results suggest that $0.60 \mu \mathrm{g} /$ $\mathrm{kg}$ of MPG-EPO administered subcutaneously or intravenously once every 2 weeks is an optimal starting dose and a suitable time interval for the initiation of anemia correction in patients with CKD, regardless of dialysis dependency.

Two Phase III studies investigated the efficacy of intravenous or subcutaneous MPG-EPO administered once every 
2 weeks in ESA-naïve patients with renal anemia who were either receiving dialysis (CERA [continuous erythropoietin receptor activator (methoxy polyethylene glycol-epoetin beta)] adMinistered Intravenously for anemia Correction and sUStained maintenance in dialysis [AMICUS]) or not (Administration of CERA in CKD patients to treat anemia with a Twice-monthly Schedule [ARCTOS]). ${ }^{16,17}$ In the AMICUS study, patients with CKD stage 5D who were receiving hemodialysis or peritoneal dialysis $(n=181)$ were recruited. After a 2-week run in, patients were randomly assigned to receive MPG-EPO or epoetin (epoetin alfa or beta). The MPG-EPO dose was started at $0.4 \mu \mathrm{g} / \mathrm{kg}$, which was adjusted to achieve a defined hemoglobin response $(\geq 11 \mathrm{~g} / \mathrm{dL})$, and an increase of $\geq 1.0 \mathrm{~g} / \mathrm{dL}$ from the patients' baseline hemoglobin levels during a 24-week correction period. Hemoglobin response rates (intent-totreat population) were $93.3 \%$ with MPG-EPO and $91.3 \%$ with epoetin. The mean changes in hemoglobin levels from baseline to the end of the correction period were $2.70 \pm 1.45 \mathrm{~g} / \mathrm{dL}$ with MPG-EPO and $2.56 \pm 1.31 \mathrm{~g} / \mathrm{dL}$ with epoetin. These results show the utility of intravenous MPG-EPO administered once every 2 weeks in ESA-naïve dialysis patients. ${ }^{16}$

In the ARCTOS study, patients who had CKD and were not receiving dialysis $(n=324)$ were recruited. Patients were randomly assigned to receive MPG-EPO once every 2 weeks or DA once weekly during an 18-week correction period and a 10-week evaluation period. The MPG-EPO dose was started at $0.6 \mu \mathrm{g} / \mathrm{kg}$ and was adjusted to achieve a defined hemoglobin response ( $\geq 11 \mathrm{~g} / \mathrm{dL})$ and an increase of $\geq 1.0 \mathrm{~g} /$ $\mathrm{dL}$ from the patients' baseline hemoglobin levels during a 28-week period after the first dose. Hemoglobin response rates were $97.5 \%$ for MPG-EPO and $96.3 \%$ for DA. The mean changes in hemoglobin levels from baseline to evaluation were $2.15 \mathrm{~g} / \mathrm{dL}$ for MPG-EPO and $2.00 \mathrm{~g} / \mathrm{dL}$ for DA. These results show that subcutaneous administration of MPG-EPO once every 2 weeks corrects anemia in ESA-naïve patients who are not receiving dialysis. ${ }^{17}$

Five Phase III maintenance studies (Maintenance of hAemoglobin eXcels with IV adMinistration of CERA [MAXIMA], ${ }^{18}$ Patients Receiving CERA Once a month for the mainTenance Of Stable hemoglobin [PROTOS], ${ }^{19}$ Stabilizing haemoglobin TaRgets in dialysis following IV CERA Treatment of Anaemia [STRIATA], TaRgeting sUstained hemogloBin in dialysis with IV and SC CERA Administration [RUBRA], and comPArator sTudy of CERA and darbepOetin alfa in patieNts Undergoing dialySis [PATRONUS]) investigated the efficacy of intravenous or subcutaneous MPG-EPO in maintaining stable hemoglobin levels in CKD patients with renal anemia on dialysis who had been converted from another ESA (epoetin alfa or beta or DA). ${ }^{18-22}$

In the MAXIMA, PROTOS, STRIATA, and RUBRA studies, patients were randomized to groups in which MPG-EPO was administered once every 2 or 4 weeks, or in which their current ESA (epoetin alfa or beta, or DA) dose was continued. ${ }^{18-22}$ Patients in these trials had been receiving hemodialysis or peritoneal dialysis and had stable baseline hemoglobin levels of $10.5-13.0 \mathrm{~g} / \mathrm{dL}$ with adequate iron status. The doses were adjusted during a 28-week titration period followed by an 8 -week evaluation period to maintain the hemoglobin levels within 10-13.5 g/dL and within $\pm 1 \mathrm{~g} / \mathrm{dL}$ of the baseline hemoglobin value. During the evaluation period, $66 \%-76 \%$ of MPG-EPO recipients, $67 \%-72 \%$ of epoetin alfa or beta recipients, and $72 \%$ of DA recipients maintained an average hemoglobin level within $\pm 1 \mathrm{~g} / \mathrm{dL}$ of baseline values. ${ }^{18-21}$ During the titration and evaluation periods, blood transfusions were required by $6 \%-12 \%$ of patients treated with MPG-EPO and $8 \%-10 \%$ of patients treated with traditional ESAs. ${ }^{18-21}$ The results of these Phase III maintenance studies demonstrate that MPG-EPO administered once every 2 or 4 weeks is comparable to epoetin alfa, epoetin beta (MAXIMA, PROTOS, RUBRA), or DA (STRIATA) in maintaining stable hemoglobin levels over the evaluation period.

Erythropoietin resistance is one of the main causes for anemia in patients with CKD. Up to $10 \%$ of patients receiving erythropoietin are hyporesponsive to the therapy and require large doses of the agent. ${ }^{24}$ All of the ESA (MPGEPO, epoetin alfa or beta, and DA) recipients maintained stable hemoglobin levels and there were no differences in percentages of blood transfusions in the above studies. ${ }^{18-21}$ These data suggest that frequency of erythropoietin resistance is similar among MPG-EPO, epoetin alfa or beta, and DA. It has been reported that the hemoglobin cycling described by Fishbane and Berns is associated with adverse outcomes such as increases in morbidity and mortality. ${ }^{25}$ Selby et al described a trend toward fewer patients on MPG-EPO (68.4\%) experiencing hemoglobin excursions than on epoetin beta $(87.8 \%, P=0.054)$, and that the MPG-EPO group also required fewer dose changes. ${ }^{26}$ These data demonstrate that the longer half-life of MPG-EPO may offer a small advantage in reducing the degree of hemoglobin variability, possibly because of fewer dose changes per patient.

The PATRONUS study was a multinational, randomized, prospective trial that compared hemoglobin maintenance 
achieved with once per month administration of MPG-EPO and DA. After the 26-week titration period using MPG-EPO once monthly or DA every 2 weeks, patients entered a second 26-week period of once per month MPG-EPO and DA. Doses of MPG-EPO increased by $6.8 \%$ and those of DA increased by $58.8 \%$ during once-monthly treatment, indicating that MPG-EPO maintained target hemoglobin more efficiently than DA at once per month dosing intervals. ${ }^{22}$

The MIRACEL study was a prospective, open-label, multicenter study performed at 90 nephrology centers in Germany, which was undertaken to examine whether monthly administration of MPG-EPO maintains stable hemoglobin levels when administered according to local clinical judgment. ${ }^{23}$ Of the 661 screened hemodialysis patients, 424 receiving epoetin or DA were converted to monthly intravenous MPG-EPO, with a 5-month titration phase followed by a 2-month evaluation phase. A mean of two MPG-EPO dose changes were required during the 7-month treatment period. During the screening, titration, and evaluation phases, mean hemoglobin was $11.7 \pm 0.7 \mathrm{~g} / \mathrm{dL}, 11.6 \pm 0.9 \mathrm{~g} / \mathrm{dL}$, and $11.4 \pm 1.0 \mathrm{~g} / \mathrm{dL}$, respectively. Patients exhibiting a change of $\leq 1 \mathrm{~g} / \mathrm{dL}$ from phase-specific individual means was $90.6 \%$, $70.4 \%$, and $82.9 \%$, respectively. These results indicate that the conversion of hemodialysis patients from epoetin or DA to monthly MPG-EPO is practical, convenient, and provides adequate control of hemoglobin levels.

\section{Tolerability}

In the MAXIMA study, ${ }^{18}$ of 673 randomized patients, 666 receiving MPG-EPO every 2 weeks $(n=221)$, MPG-EPO every 4 weeks $(n=220)$, or epoetin $1-3$ times per week $(n=225)$ received at least one treatment. At least one adverse event was reported in $619(93 \%)$ of patients (MPG-EPO every 2 weeks [ $n=203]$, MPG-EPO every 4 weeks [ $=202]$, or epoetin 1-3 times per week [ $n=214]$ ); most adverse events were mild to moderate. The incidence of adverse events did not differ between groups $(P=0.12)$.

The most commonly reported adverse effects were hypertension, nasopharyngitis, headache, and diarrhea. In addition, 287 patients had serious adverse events in the three groups (MPG-EPO every 2 weeks $[n=101]$, MPG-EPO every 4 weeks $[n=87]$, or epoetin $1-3$ times per week [n =99]). The most common serious adverse events were sepsis, pneumonia, and arteriovenous graft thrombosis. Only six patients had serious adverse events that were judged to be treatment related and the occurrence of serious adverse events did not differ between groups (MPG-EPO every 2 weeks [n=3], MPG-EPO every 4 weeks $[n=2]$, or epoetin $1-3$ times per week $[\mathrm{n}=1] ; P=0.40$ ) (Table $3 \mathrm{~A}$ ). The results of the PROTOS study were similar to those of the MAXIMA study. In total, $90 \%$ of patients across all treatment groups (twice per month MPG-EPO [90.0\%], once per month MPG-EPO [93.2\%], or epoetin 1-3 times weekly [87.4\%]) experienced at least one adverse event.

The most commonly reported adverse effects were hypertension, procedural hypotension (hypotension during dialysis), nasopharyngitis, headache, and diarrhea. Most events were mild or moderate in intensity and were evenly distributed across the different treatment groups. The incidence of treatment-related adverse events was low (twice-monthly MPG-EPO, 4\%; once-monthly MPG-EPO, $6 \%$; and epoetin 1-3 times weekly, $2 \%$ ). Only one death was considered to be related to study treatment (once-monthly MPG-EPO; gastrointestinal necrosis followed by sepsis) (Table 3B). ${ }^{19}$ In addition, the occurrences of cerebral hemorrhage $(0.2 \%)$, myocardial infarction $(0.2 \%)$, and hypertensive encephalopathy $(0.2 \%)$ were limited, according to the patient package insert from the pharmaceutical company. ${ }^{27}$ These results indicate that MPG-EPO is as well tolerated and safe as conventional ESA treatments. However, the long-term adverse effects of MPG-EPO need to be ascertained.

Pain following subcutaneous administration of MPG-EPO or DA was compared among healthy volunteers $(n=84)$. Pain was assessed on a $100 \mathrm{~mm}$ visual analog scale immediately after drug administration. Visual analog scale was $21.5 \mathrm{~mm}$ for MPG-EPO and $33.4 \mathrm{~mm}$ for DA $(P<0.0001)$, showing that subcutaneous injection of MPG-EPO is significantly less painful than subcutaneous injection of DA. ${ }^{28}$

\section{Pharmacoeconomics}

An observational time and motion study was carried out in twelve dialysis centers in the UK and Germany (six centers per country). ${ }^{29}$ Time measurements for observed tasks were obtained by trained observers using a stopwatch. Cost results in 2006 were expressed as average observed costs, including staff costs for observation periods and costs of supplies. ESA drug acquisition costs were not considered in the analysis. According to this study, the estimated average total annual costs for traditional ESA treatment for a hypothetical center of 100 dialysis patients were $€ 17,031$ and GBP£18,739 for German and UK centers, respectively. Assuming 100\% conversion from traditional ESAs to once-monthly MPG-EPO in a hypothetical center of 100 dialysis patients, the estimated time savings were 36.9 days per year in an average UK center, and 43.4 days per year in an average German center. This leads to an estimated reduction in annual costs of $€ 9,798$ 
Table 3 Adverse events of methoxy polyethylene glycol-epoetin beta

\begin{tabular}{|c|c|c|c|}
\hline Adverse events & $\begin{array}{l}\text { Methoxy polyethylene } \\
\text { glycol-epoetin beta every } 2 \text { weeks } \\
(n=22 I)\end{array}$ & $\begin{array}{l}\text { Methoxy polyethylene } \\
\text { glycol-epoetin beta every } \\
4 \text { weeks }(n=220)\end{array}$ & $\begin{array}{l}\text { Epoetin I-3 times } \\
\text { per week } \\
(\mathrm{n}=225)\end{array}$ \\
\hline \multicolumn{4}{|c|}{ (A) Adverse events in the MAXIMA study ${ }^{18}$} \\
\hline Any adverse event & $203(92 \%)$ & 202 (92\%) & $2 \mid 4(95 \%)$ \\
\hline Diarrhea & $38(17 \%)$ & $26(12 \%)$ & $30(13 \%)$ \\
\hline Nasopharyngitis & $28(13 \%)$ & $39(18 \%)$ & $24(11 \%)$ \\
\hline Hypertension & $23(10 \%)$ & $29(13 \%)$ & $35(16 \%)$ \\
\hline Arteriovenous graft thrombosis & $25(11 \%)$ & $26(12 \%)$ & $32(14 \%)$ \\
\hline Upper respiratory tract infection & $20(9 \%)$ & $30(14 \%)$ & $25(11 \%)$ \\
\hline Headache & $30(14 \%)$ & $17(8 \%)$ & $24(11 \%)$ \\
\hline Fluid overload & $27(12 \%)$ & $22(10 \%)$ & $17(8 \%)$ \\
\hline Muscle spasms & $19(9 \%)$ & $19(9 \%)$ & $24(11 \%)$ \\
\hline Serious adverse events & I0I (46\%) & $87(40 \%)$ & 99 (44\%) \\
\hline Sepsis & $5(2 \%)$ & $6(3 \%)$ & $9(4 \%)$ \\
\hline Pneumonia & $9(4 \%)$ & $5(2 \%)$ & $5(2 \%)$ \\
\hline \multirow[t]{2}{*}{ Arteriovenous graft thrombosis } & $2(1 \%)$ & $8(4 \%)$ & $7(8 \%)$ \\
\hline & $\begin{array}{l}\text { Twice-monthly CERA } \\
(\mathrm{n}=190)\end{array}$ & $\begin{array}{l}\text { Once-monthly CERA } \\
(n=191)\end{array}$ & $\begin{array}{l}\text { Epoetin I-3 times } \\
\text { per week }(n=191)\end{array}$ \\
\hline \multicolumn{4}{|c|}{ (B) Adverse events in the PROTOS study ${ }^{19}$} \\
\hline Hypertension & $27(14 \%)$ & $30(16 \%)$ & $25(13 \%)$ \\
\hline Procedural hypotension & $17(9 \%)$ & $29(15 \%)$ & $20(10 \%)$ \\
\hline Nasopharyngitis & $18(9 \%)$ & $19(10 \%)$ & $18(9 \%)$ \\
\hline Headache & $15(8 \%)$ & $20(11 \%)$ & $19(10 \%)$ \\
\hline Diarrhea & $20(11 \%)$ & $15(8 \%)$ & $14(7 \%)$ \\
\hline Muscle spasms & $16(8 \%)$ & 14 (7\%) & $17(9 \%)$ \\
\hline Fluid overload & $9(5 \%)$ & $15(8 \%)$ & $18(9 \%)$ \\
\hline Arteriovenous fistula site hemorrhage & $18(9 \%)$ & $15(8 \%)$ & $5(3 \%)$ \\
\hline Arteriovenous fistula thrombosis & $13(7 \%)$ & $15(8 \%)$ & $8(4 \%)$ \\
\hline Angina pectoris & $2(1 \%)$ & $15(8 \%)$ & $4(2 \%)$ \\
\hline Any adverse events & 170 (90.0\%) & $177(93.2 \%)$ & 167 (87.4\%) \\
\hline Serious adverse events & $70(36.8 \%)$ & $73(38.4 \%)$ & $85(44.5 \%)$ \\
\hline
\end{tabular}

Abbreviation: CERA, continuous erythropoietin receptor activator (methoxy polyethylene glycol-epoetin beta).

$(-58 \%)$ for the German center and GBP£6,615 (-35\%) for the UK center. These data suggest that once-monthly MPGEPO reduces the overall time and cost associated with anemia management in CKD patients on dialysis compared with the use of traditional ESAs.

\section{Dosage and administration}

In ESA-naïve patients, the recommended starting dose is $0.6 \mu \mathrm{g} / \mathrm{kg}$ administered once every 2 weeks as a subcutaneous or intravenous injection, in order to reach a hemoglobin level of $>11 \mathrm{~g} / \mathrm{dL}$. The dose may be increased by approximately $25 \%$ if hemoglobin levels increase by $<1.0 \mathrm{~g} / \mathrm{dL}$ over a month. Further increases of approximately $25 \%$ may be made once per month until the individual target hemoglobin level is reached. If a hemoglobin level of $>11 \mathrm{~g} / \mathrm{dL}$ is reached for an individual patient, MPG-EPO may be continued once per month using a dose equal to twice the previous dose once every 2 weeks.
Patients currently being treated with ESA can be directly converted to MPG-EPO administered once per month as a single intravenous or subcutaneous injection. The starting dose of this agent is based on the calculated weekly equivalent dose of DA or epoetin at the time of conversion (Table 4). The first injection of MPG-EPO should start at the next scheduled dose of the previously administered DA or epoetin dose.

In patients receiving treatment with ESA and in those naïve to ESA, the MPG-EPO dose should be reduced by approximately $25 \%$ if the hemoglobin level increases by more than $2 \mathrm{~g} / \mathrm{dL}$ in 1 month or if the hemoglobin level approaches $12 \mathrm{~g} / \mathrm{dL}$. If hemoglobin levels continue to increase, MPG-EPO administration should be interrupted until these levels begin to decrease (a decrease of approximately $0.35 \mathrm{~g} / \mathrm{dL}$ per week is expected). Therapy should then be resumed at a dose approximately $25 \%$ less than the 
Table 4 Recommended starting dose of methoxy polyethylene glycol-epoetin beta in patients with anemia associated with chronic kidney disease previously treated with erythropoiesis-stimulating agents

\begin{tabular}{lll}
\hline $\begin{array}{l}\text { Previous weekly IV or SC darbepoetin } \\
\text { alfa dose }(\mu \mathrm{g} / \text { week) }\end{array}$ & $\begin{array}{l}\text { Previous weekly IV or SC epoetin } \\
\text { dose (IU/week) }\end{array}$ & $\begin{array}{l}\text { Monthly IV or SC methoxy polyethylene } \\
\text { glycol-epoetin beta dose }(\mu \mathrm{g} / \text { month) }\end{array}$ \\
\hline$<40$ & $<8000$ & 120 \\
$40-80$ & $8000-16000$ & 200 \\
$>80$ & $>16000$ & 360 \\
\hline
\end{tabular}

Abbreviations: IV, intravenous; SC, subcutaneous.

previously administered dose. Dose adjustments should not be made more frequently than once per month.

Since treatment experience is limited in patients receiving peritoneal dialysis, regular hemoglobin monitoring and strict adherence to dose adjustment guidance is recommended in this population. . $^{30,31}$

\section{Conclusion}

Among patients with anemia associated with CKD, regardless of whether the patient is receiving dialysis, subcutaneous or intravenous administration of MPG-EPO achieves a high hemoglobin response rate in ESA-naïve patients when administered once every 2 weeks and maintains stable hemoglobin levels in patients previously treated with ESAs when administered once per month. MPG-EPO is as well tolerated and safe as traditional ESA treatments. In addition, compared with the use of traditional ESAs, administration of MPG-EPO may reduce the overall time and cost associated with anemia management in CKD patients.

\section{Disclosure}

The authors report no conflicts of interest in this work.

\section{References}

1. Go AS, Chertow GM, Fan D, McCulloch CE, Hsu CY. Chronic kidney disease and the risks of death, cardiovascular events, and hospitalization. N Engl J Med. 2004;351(13):1296-1305.

2. Kidney Disease Outcomes Quality Initiative, National Kidney Foundation. KDOQI clinical practice guidelines and clinical practice recommendations for anemia in chronic kidney disease. Am J Kidney Dis. 2006;47(5 Suppl 3):S11-S145.

3. Silverberg DS, Wexler D, Sheps D, et al. The effect of correction of mild anemia in severe, resistant congestive heart failure using subcutaneous erythropoietin and intravenous iron: a randomized controlled study. J Am Coll Cardiol. 2001;37(7):1775-1780.

4. Halstenson CE, Macres M, Katz SA, et al. Comparative pharmacokinetics and pharmacodynamics of epoetin alfa and epoetin beta. Clin Pharmacol Ther. 1991;50(6):702-712.

5. Robinson DM, Easthope SE. Darbepoetin alfa: its use in anemia associated with chronic kidney disease. Bio Drugs. 2005;19(5):327-343.

6. Padhi D, Ni L, Cooke B, Marino R, Jang G. An extended terminal halflife for darbepoetin alfa: results from a single-dose pharmacokinetic study in patients with chronic kidney disease not receiving dialysis. Clin Pharmacokinet. 2006;45(5):503-510.
7. Macdougall IC, Gray SJ, Elston O, et al. Pharmacokinetics of novel erythropoiesis stimulating protein compared with epoetin alfa in dialysis patients. J Am Soc Nephrol. 1999;10(11):2392-2395.

8. Macdougall IC, Robson R, Opatrna S, et al. Pharmacokinetics and pharmacodynamics of intravenous and subcutaneous continuous erythropoietin receptor activator (C.E.R.A.) in patients with chronic kidney disease. Clin J Am Soc Nephrol. 2006;1(6):1211-1215.

9. Macdougall IC, Eckardt KU. Novel strategies for stimulating erythropoiesis and potential new treatments for anaemia. Lancet 2006;368(9539):947-953.

10. Jarsch M, Brandt M, Lanzendörfer M, Haselbeck A. Comparative erythropoietin receptor binding kinetics of C.E.R.A. and epoetin-beta determined by surface plasmon resonance and competition binding assay. Pharmacology 2008;81(1):63-69.

11. Fishbane S, Pannier A, Liogier X, Jordan P, Dougherty FC, Reigner B. Pharmacokinetic and pharmacodynamic properties of methoxy polyethylene glycol-epoetin beta are unaffected by the site of subcutaneous administration. J Clin Pharmacol. 2007;47(11): $1390-1397$.

12. de Francisco AL, Sulowicz W, Klinger M, et al; BA16260 Study Investigators. Continuous Erythropoietin Receptor Activator (C.E.R.A.) administered at extended administration intervals corrects anaemia in patients with chronic kidney disease on dialysis: a randomised, multicentre, multiple-dose, phase II study. Int J Clin Pract. 2006;60(12):1687-1696.

13. Besarab A, Salifu MO, Lunde NM, et al; Ba16285 Study Investigators. Efficacy and tolerability of intravenous continuous erythropoietin receptor activator: a 19-week, phase II, multicenter, randomized, open-label, dose-finding study with a 12-month extension phase in patients with chronic renal disease. Clin Ther. 2007;29(4):626-639.

14. Locatelli F, Villa G, de Francisco AL, et al; BA16286 Study Investigators. Effect of a continuous erythropoietin receptor activator (C.E.R.A.) on stable haemoglobin in patients with CKD on dialysis: once monthly administration. Curr Med Res Opin. 2007;23(5): 969-979.

15. Provenzano R, Besarab A, Macdougall IC, et al; BA 16528 Study Investigators. The continuous erythropoietin receptor activator (C.E.R.A.) corrects anemia at extended administration intervals in patients with chronic kidney disease not on dialysis: results of a phase II study. Clin Nephrol. 2007;67(5):306-317.

16. Klinger M, Arias M, Vargemezis V, et al. Efficacy of intravenous methoxy polyethylene glycol-epoetin beta administered every 2 weeks compared with epoetin administered 3 times weekly in patients treated by hemodialysis or peritoneal dialysis: a randomized trial. Am J Kidney Dis. 2007;50(6):989-1000.

17. Macdougall IC, Walker R, Provenzano R, et al; ARCTOS Study Investigators. C.E.R.A. corrects anemia in patients with chronic kidney disease not on dialysis: results of a randomized clinical trial. Clin J Am Soc Nephrol. 2008;3(2):337-347.

18. Levin NW, Fishbane S, Cañedo FV, et al; MAXIMA Study Investigators. Intravenous methoxy polyethylene glycol-epoetin beta for haemoglobin control in patients with chronic kidney disease who are on dialysis: a randomised non-inferiority trial (MAXIMA). Lancet. 2007;370(9596):1415-1421. 
19. Sulowicz W, Locatelli F, Ryckelynck JP, et al; PROTOS Study Investigators. Once-monthly subcutaneous C.E.R.A. maintains stable hemoglobin control in patients with chronic kidney disease on dialysis and converted directly from epoetin one to three times weekly. Clin J Am Soc Nephrol. 2007;2(4):637-646.

20. Canaud B, Mingardi G, Braun J, et al; STRIATA Study Investigators. Intravenous C.E.R.A. maintains stable haemoglobin levels in patients on dialysis previously treated with darbepoetin alfa: results from STRIATA, a randomized phase III study. Nephrol Dial Transplant. 2008;23(11):3654-3661.

21. Spinowitz B, Coyne DW, Lok CE, et al; RUBRA Study Investigators. C.E.R.A. maintains stable control of hemoglobin in patients with chronic kidney disease on dialysis when administered once every two weeks. Am J Nephrol. 2008;28(2):280-289.

22. Carrera F, Lok CE, de Francisco A, et al; PATRONUS Investigators. Maintenance treatment of renal anaemia in haemodialysis patients with methoxy polyethylene glycol-epoetin beta versus darbepoetin alfa administered monthly: a randomized comparative trial. Nephrol Dial Transplant. 2010;25(12):4009-4017.

23. Fliser D, Kleophas W, Dellanna F, et al. Evaluation of maintenance of stable haemoglobin levels in haemodialysis patients converting from epoetin or darbepoetin to monthly intravenous C.E.R.A.: the MIRACEL study. Curr Med Res Opin. 2010;26(5):1083-1089.

24. van der Putten K, Braam B, Jie KE, Gaillard CA. Mechanisms of disease: erythropoietin resistance in patients with both heart and kidney failure. Nat Clin Pract Nephrol. 2008;4(1):47-57.
25. Fishbane S, Berns JS. Hemoglobin cycling in hemodialysis patients treated with recombinant human erythropoietin. Kidney Int. 2005; 68(3):1337-1343.

26. Selby NM, Fonseca S, Fluck R, Taal MW. Hemoglobin variability with epoetin beta and continuous erythropoietin receptor activator in patients on peritoneal dialysis. Perit Dial Int. 2012;32(2):177-182.

27. MIRCERA ${ }^{\circledR}$ : methoxy polyethylene glycol-epoetin beta [product information]. Dee Why, Australia: Roche; 2010. Available from: http://www. roche-australia.com/fmfiles/re7229005/downloads/anaemia/mircera-pi. pdf. Accessed March 23, 2012.

28. Pannier A, Jordan P, Dougherty FC, Bour F, Reigner B. Subcutaneous injection pain with C.E.R.A., a continuous erythropoietin receptor activator, compared with darbepoetin alfa. Curr Med Res Opin. 2007; 23(12):3025-3032.

29. Saueressig U, Kwan JT, De Cock E, Sapède C. Healthcare resource utilization for anemia management: current practice with erythropoiesis-stimulating agents and the impact of converting to oncemonthly C.E.R.A. Blood Purif. 2008;26(6):537-546.

30. Roche. Micera ${ }^{\circledR}$ solution for injection in pre-filled syringe [summary of product characteristics]. Welwyn Garden City: Roche Ltd; 2012. Available from: http://www.medicines.org.uk/emc/medicine/19960/SPC/. Accessed February 21, 2012.

31. Locatelli F, Aljama P, Bárány P, et al; European Best Practice Guidelines Working Group. Revised European best practice guidelines for the management of anaemia in patients with chronic renal failure. Nephrol Dial Transplant. 2004;19 Supp1 2:ii1-ii47.

\section{Publish your work in this journal}

The International Journal of Nephrology and Renovascular Disease is an international, peer-reviewed open-access journal focusing on the pathophysiology of the kidney and vascular supply. Epidemiology, screening, diagnosis, and treatment interventions are covered as well as basic science, biochemical and immunological studies. The journal welcomes original research, clinical studies, reviews \& evaluations, expert opinion and commentary, case reports and extended reports. The manuscript management system is completely online and includes a very quick and fair peerreview system, which is all easy to use. Visit http://www.dovepress.com/ testimonials.php to read real quotes from published authors. 